\title{
Reflections on Occupying
}

\section{Dennis Fox}

\begin{abstract}
The Occupy Wall Street movement's emphasis on egalitarian decision making, mutual aid, and direct action originates in anarchist political practice even though most Occupiers are not anarchists and many hope to achieve a variety of liberal political reforms. Although the most immediate threats to Occupy are police repression and the stresses of winter, a more substantive threat is internal divisiveness over goals, tactics, and process as the movement responds inconsistently to external pressure and internal strain. A critical psychologist reflects on his experiences in the early stages of the movement in Boston and Florida, where he taught on-site classes designed to encourage appreciation of, and support for, radical rather than reformist goals.
\end{abstract}

Keywords. occupy, activism, anarchism, organizing

Less than two weeks after Occupy Wall Street activists took over Manhattan's Zuccotti Park, several hundred of their Massachusetts peers began to Occupy Boston. On September $30^{\text {th }}$, 2011, after three evenings of planning meetings held on Boston Common, the group moved to Dewey Square, a section of the Greenway on the edge of the Financial District, across the street from South Station and the Federal Reserve building. Two months after Occupy Wall Street began and a few days after New York City police cleared out Zuccotti Park, Boston's occupiers are still at Dewey, building on their successes, facing growing challenges, and adapting to rapidly changing local and national circumstances. At Occupy sites across the country, things are changing fast.

Regardless of what happens next, the Occupy experience has impressed and energized me from the very beginning. Despite the inevitable internal tensions I touch on below, the 
competing analyses and strategies debated on the Internet and within every Occupy group, and the frantic police efforts to shut down Occupy, the movement quickly and unexpectedly became a phenomenon with the potential to transform the political landscape. It is too soon to know for sure if any such transformation will occur. After decades of intermittent activism, my internal cynic warns me not to expect much more than a temporary boost for liberal politicians. But for now, I continue to imagine the movement's resourcefulness and spontaneity helping to spark something new, turning even site evictions into the beginning of a new phase.

My motivation to Occupy has been political rather than academic, but the dividing line between my different lives has never been very sharp - political, academic, and personal perceptions and experiences interlock in ever-changing ways. The first night at Dewey Square, I brought my sleeping bag and other equipment, but after lugging everything around I was too tired to try to sleep through the loud dance party taking form amidst the 20 or so tents that had arisen on the grass (which grew to more than 130 a month later). My past political comrades nowhere to be seen, I felt out of sorts. But every afternoon for the next two weeks, and then most days for the next three, I took the subway downtown to spend five or more hours at Dewey before returning home to catch up on the news, post photos online (http://www.flickr.com/photos/dennisfox/sets/72157627803654492/), and occasionally blog (http://blog.dennisfox.net). More recently, in Florida visiting family, I've been taking part in Occupy Palm Beach County as best I can.

Perhaps my most important role at Occupy Boston was being a 62 year old man. I was never the only older participant, but Boston's occupiers are overwhelmingly in their 20s and 30s. The few graybeards marching along through downtown financial, shopping, and tourist districts, taking part in planning meetings, and helping defend an attempted camp expansion have helped counter mainstream claims that Occupy is just for kids. Just being there is useful, at least in places that are similarly youth dominated (unlike Occupy Palm Beach County, for example, which is more diverse in both age and race despite being much smaller). But adapting to a different generation's tone has sometimes been jarring. My first blog posting included this:

My impression so far is generally positive. It's great seeing so much youthful anti-capitalist energy. The Twitter feed is constant with schedule changes, appeals for supplies, weather reports; my favorite so far was the tweet reporting that a "dad-like guy dropped off four cases of soda!" Lots of people speaking up in groups are articulate, focused, and experienced dealing with organizational and tactical issues. It's exciting! When it doesn't drone on! (10/2/2011)

Signing up for Twitter to keep track of fast-changing developments was just one of many adjustments. Another was trying not to come off like an old white guy giving too much advice.

At Dewey, I focused my efforts on three Working Groups: the Free School University (FSU), which coordinates professors and activists who come to Dewey to teach, lecture, and lead discussions about issues related to Occupy as well as more tangential topics; the intermittent anarchist caucus, which met several times; and the facilitation working group, which I found too frustrating to remain active in. My frustration was evident early on:

The group holds large General Assemblies twice a day, which can go on for a long time. At the planning assembly I went to last week I was impressed with the ability to reach 
decisions as a group. On site the process seems to me more forced. Decisions are mostly made by smaller groups (Tactics, Legal, Medical, Outreach, Media, etc.) and then proposed and sometimes sort-of discussed and voted on by a modified consensus process; that process seems to work partly by peer pressure to not block things, or else some decisions are just put off. There's no clear mechanism to really present and discuss competing arguments, as far as I can tell, and no affinity group structure that might enable discussions and decisions in small groups other than the working groups. $(10 / 2 / 2011)$

\section{A few days later I added this:}

It seems to me that the GA is bogged down in process. There's a lot of grumbling about inability to just talk about things. Lots of people don't go to the GA (or, like me, don't stay long). It often seems that the facilitators have their own agenda, and in their effort to avoid conflict sometimes over-structure things. I also think there's a basic misuse of the language of consensus. They claim to use "modified consensus" but in fact use a $75 \%$ supermajority rule, with people who "block" not actually preventing decisions from being made. I attended a facilitators meeting yesterday, where this confusion seemed clear, without much interest in re-thinking all this. Also, as I've noted previously, there's no small-group affinity group structure, no system of spokespersons to coordinate decision making among the different groups. Perhaps this will change.... (10/7/2011)

\section{Political Education}

I decided early on to focus on the Free School University. No doubt this reflected my academic bias that education is a good thing as well as my political bias that Occupy's goals should be radical rather than reformist. Despite Occupy's often-radical language, styles, and norms, the wide array of inconsistent demands listed in proposed statements and trumpeted on protest signs revealed a largely moderate-progressive mindset. In places like Boston where initially Occupiers were disproportionately white middle-class educated young people confronting a bleaker than expected future, concerns about student loans, lack of jobs, and home foreclosures dominated. For many, the hoped-for remedy was to change a few laws and replace greedy corporate executives and conservative politicians with more honest liberal versions - but at the same time, many Occupiers were disillusioned with a political process that had led to the fervor around Barack Obama's 2008 presidential campaign only to be followed by a failure to seek, let alone deliver, promised change. There was increasing awareness that traditional political activity had little chance of success against the corrupting impact of corporate power.

Given these conflicting motivations and perceptions, it seemed to me that on-site education could help Occupiers explore the links between whatever brought them to Dewey Square and more radical analyses focused on changing the system rather than the players. It could suggest that the mainstream focus on middle-class decline over the past 30 years masks capitalism's inherent inequality even before Ronald Reagan's feel-good, greed-is-good era - that the problems of those in the newly distressed middle class are connected to the poverty, police brutality, and other problems the bottom rungs of the $99 \%$ have always encountered. Free School University, in other words, could help radicalize Occupiers and prepare the way for divisive days to come. 
Through FSU, thus, a group of mostly Marxist academics organized the Howard Zinn Memorial Lecture Series, as did another group affiliated with Dollars and Sense Magazine. Dozens of individual teachers came forward to schedule their own topics, meeting with groups ranging from half a dozen students to 50 or 60 at a time. FSU became an increasingly busy working group, at times struggling to keep up with the many offers to teach amidst challenges of finding space, megaphones, and open slots in the schedule (http://wiki.occupyboston.org/wiki/Free_School_University_(FSU)).

Through FSU I taught five classes on three topics over a three-week period. The classes reflected my political sense of what was needed and would be welcomed given the Occupy context, my academic specialty areas, and my personal interests. The class descriptions provide some context for my ongoing reflections about the movement. As an aside, I want to note that this was some of the most enjoyable teaching of my life, offering the rare ability to teach interested and engaged people eager to be there right at the very moment class was in session.

\section{Class 1: Anarchism, Psychology, and Law}

My first class drew perhaps 40 participants on a sunny Saturday afternoon, most of them relatively unfamiliar with anarchism (the same topic three weeks later on a damp, dark, depressing mid-week afternoon drew a much smaller group). This was October $8^{\text {th }}$, just a week after Occupy Boston began, when sometimes-fearful talk of anarchists was already surfacing at Occupy sites across the country. In class I explained my own sense of anarchism's relevance, as introduced in the online class notice:

Anarchists traditionally want both autonomy (individuality, independence, personal liberation) and community (cooperation, connection, mutual aid). Underlying their political and philosophical critiques of capitalism and the state are psychological assumptions about power, hierarchy, and similar dynamics. In this discussion we will explore anarchist thinking about human nature and the nature of society, focusing especially on the development and purpose of law.

As I've explored elsewhere, anarchism's tension between individuality and community and its insistence on acting today in ways that "prefigure" the desired future make social psychology particularly relevant (Fox, 1985, 2011). In class, I pointed out that even though most Occupiers are not anarchists, Occupy norms reflect anarchist theory and practice. From horizontal decision-making and the refusal to create a formal leadership hierarchy, to the free provision of food, clothing, and medical care, to emphasizing direct action rather than traditional forms of political lobbying and petitioning, Dewey Square was an experiment in how to create anarchist community. Most anarchists at Dewey Square, I noted, were not wearing black bandanas; they were active in the food tent (where Food Not Bombs, a national anarchist network, plays a central role), the medic tent, even the facilitation and legal tents. For many in the workshop, this was news. Also news was my description of how these now-familiar norms developed in the Boston area during the 1970s movement against construction of the Seabrook, New Hampshire nuclear plant, which many older New England activists participated in through the Clamshell Alliance and Coalition for Direct Action at Seabrook (Epstein, 1993); that's where Food Not Bombs began as well. I also suggested that, as an experiment in nonhierarchical community, Occupy was bound to make mistakes, but that we could learn from our mistakes and try new approaches. (The online class description links to a three-part video of this session: 
https://www.facebook.com/event.php?eid=254875744550119.) I am now scheduled to teach a variation of this class at Occupy Palm Beach County's first teach-in, in just a few hours.

\section{Class 2: Anarchist Occupation Issues}

My second class addressed differences over goals, tactics, and process that were already creating tensions around the country, as explained in the October $9^{\text {th }}$ notice $I$ posted for an October $11^{\text {th }}$ class:

In this discussion we will explore a range of issues that have, or might yet, come before Boston's General Assembly and various working groups, including among others:

- message, principles, demands: what do anarchists want and what can they live with? should we call for legislative reform or revolutionary change? ending corporate greed or ending corporations? better law or no law?

- focus: how does the effort to portray the $99 \%$ as a unified class contribute to our overwhelmingly white middle-class composition and marginalize the interests of those at the bottom of the $99 \%$ ?

- police: how should we relate to those whose job it is to enforce the will of the $1 \%$ ?

- direct action: if direct action means acting directly, how should anarchists relate to petitions and similar actions that ask the authorities to pass a law, change a rule, or amend the Constitution?

- tone: how do we resolve the tension between those who want nonthreatening actions designed to draw in people with more moderate views and those who believe more militant language and/or action is necessary to get to the heart of what we want to accomplish?

- illegality, civil disobedience, nonviolence, confrontation, property destruction, diversity of tactics: conflicting definitions and conflicting views

- hierarchical decision-making and leadership: how does a movement committed to horizontalism prevent hierarchy and other forms of power imbalance?

- consensus: what does consensus mean, and is it necessary? is consensus about intensely divisive issues really possible in the absence of fundamental political agreement, and if not, what are the alternatives?

- meeting process: when does agreed-upon process become a barrier to communication?

- collaboration: how can people with vastly different analyses, goals, and methods work together effectively?

The intent of this workshop is to help anarchists and nonanarchists get a better sense of what's at stake on these and other issues. My primary role is to help identify questions; my own answers are incomplete and changeable.

By coincidence, on Monday afternoon, October $10^{\text {th }}$, a group of Occupiers expanded the crowded Dewey Square tenting site to the next block up the Greenway, an autonomous action taken without seeking consensus. Although this move was in accordance with a previous General Assembly decision to allow such autonomous actions, not everyone on site was pleased 
to see this provocative move. Still, a General Assembly held on the expanded site agreed by consensus to nonviolently defend it against the police, who had given a midnight deadline. A few hours later, the police arrested more than 140 of us as we linked arms around the tents.

And so, when Anarchist Occupation Issues met Tuesday afternoon, we had an unplanned reallife incident to illustrate some of Occupy's diverse internal perspectives. And of course, in the time since then, internal divisions have become much more public and at times self-destructive at Occupy sites across the country.

\section{Class 3: Challenging Basic Assumptions: Personal and Political}

My third class, taught twice, was not explicitly anarchist though consistent with it:

The Occupy movement challenges institutions that take for granted what's best for everyone. Those in power - the top $1 \%$ and those lower down who serve political and economic elites - claim to know what people everywhere are capable of doing and imagining. This approved ideological view of what make sense spreads throughout society, affecting all of us through media, schools, popular entertainment, organized religion, and other institutions that teach us to restrict our sense of what's possible and what's desirable. And so even as we come to understand there's something wrong with things as they are, we're not always sure what can really be changed.

In this continuing discussion we will talk about things we take for granted about human society and human nature, about why we believe what we believe and how we might explore alternatives in our personal, interpersonal, and community lives.

- What do we assume about national well-being, the virtues of technology and materialism and modernity, the necessity of nation states and multinational corporations?

- How do these beliefs relate to assumptions about our own personal and interpersonal well-being, to our sense of inevitability about things like hierarchy, competition, jealousy, possessiveness?

- What difficulties have we encountered trying to change assumptions and habits we grew up with?

- What successes can we share?

- What can we create together here at Dewey Square and beyond?

This class too led to extended discussion, reaching a range of topics reflecting not just assumptions about economic issues but also the links between the political and the personal. My thinking about these links (Fox, 2011) parallels the views of many anarchists, feminists, and others over the years. How can people who grow up in a particular culture change that culture when we don't fully know how to put into practice the alternative ways of interacting we believe in? As tensions rise at Occupy sites across the country, I think we would do better if we had more skills to help us cooperate, coordinate, listen, and learn as well as more experience exploring the sources of our own emotions and impulses. 


\section{Transitions}

I write this several days after Occupy Wall Street tried to actually shut down Wall Street with a massive protest on the movement's two-month anniversary. Zuccotti Park is now emptied of tents, at least for the moment. Police have shut down other Occupy sites across the country, though not yet Boston, where the Winterization Working Group remains busy. Police pressure, cold weather, and the ongoing stresses of conflicting goals and tactics have brought to the fore internal debates clearly foreseeable at the beginning. Even in early October, I blogged,

There's a lot of talk about coming up with a clear statement of demands, largely in response to national media mocking the Occupy groups for not being clear. My sense is that any list of specifics will break things apart. I much prefer leaving things fluid, partly because any specifics will get into liberal reform minutiae inconsistent with what I think is the radical restructuring we need, and I don't think the group as a whole would adopt Ending Capitalism. (10/7/2011)

I continue to believe that efforts to "clarify demands" can only moderate the message and drain the movement of its creative energy. Rather than accommodating those who seek to place Occupy in pre-determined categories and deflect it in mainstream directions, I'd much prefer a vague sense of shared values, perhaps around the notion that even if we don't all agree on solutions, what holds us together is understanding that economic policy is out of our hands. The $1 \%$ have power over our lives because in our system economic decisions are not made by the $99 \%$. From this notion, which seems to me to reflect the general sense of the movement, Occupy might move in either reformist or radical directions. Trying to specify demands readily achievable in our current system would likely convert the movement into something resembling MoveOn.org or the Progressive Democrats of America, a far cry from imagining systemic transformation. Site occupations may not survive the current repression and cold weather, but the movement's most important achievements - focusing attention on imbalance of power and resisting disempowering reformist action - can persist in other forms if we avoid premature caving in.

As noted above, differences within the movement between liberals/progressives on the one hand and various radical approaches extend to a variety of goals and tactics. Setting aside for the moment my own preferences, it's hard to see Occupy persisting if it becomes merely another liberal interest group. What would it contribute that's new? Much of its energy comes from building on anarchist process even without using the label, and much of its draw comes from thumbing its nose at processes that routinely co-opt activists and lead to minimal change. If Occupy becomes easy to categorize and predict, if it endorses politicians who promise to outObama Obama, there won't be much justification for it. Instead, I believe our strength comes partly in being uncontrollable. Occupy has already made discussion of class differences reasonable rather than ridiculous; mainstream liberal politicians can build on that opening to push their own agendas, but the details are not what Occupy itself should focus on.

Unfortunately, these internal debates are already pushing some toward mainstreaming. The divisions evident in the North and West have reached my current South Florida location. As explained to me after last weekend's General Assembly, occupiers originally set up in West Palm Beach's most visible downtown park, between the weekly Greenmarket and the Intracoastal Canal separating the mainland from Palm Beach, one of the nation's most obvious 1\% havens. 
When the city declared this park off limits, the group debated whether to hold their ground or accept a permit for a spacious but less visible park a block away. Those who refused to accept the deal were in the minority, and evidently stayed away when the majority agreed to move. I'm not sure what happened to those who moved on. Perhaps they'll attend this afternoon's teach-in on Anarchism and Psychology or reconnect in some other way. I hope so. I'm not sure that even an extended Occupation can have much impact if the goal and means become indistinguishable from traditional reform efforts. One good sign is that a new Direct Action Working Group is talking about civil disobedience.

There's similar movement in Boston. Yesterday an Occupy Boston Summit addressed a range of contentious issues. That was planned weeks ago, but now there are new issues to consider. In the wake of police action in other cities, Occupy Boston's supporters in the National Lawyers Guild and American Civil Liberties Union obtained an injunction to prevent the police from shutting down Dewey Square, which Occupy Boston had never requested a permit for. From here in Florida it's not clear to me how the injunction strategy was presented and debated. But when the judge also ordered both sides to enter mediation, the General Assembly "temporarily empowered" three Occupiers to represent the movement; even though they do not have the power to make decisions without returning to GA for approval, it's hard not to think about slippery slopes. The core of direct action - acting directly rather than asking for permission or acknowledging the legitimacy of authorities to make decisions for us - has been warped as segments of the movement across the country are bending under pressure.

Much of the criticism of Occupy seems overblown. Authorities intent on rationalizing the use of riot police to dismantle tents have magnified isolated incidents of on-site violence and unsanitary conditions to justify massive use of force against mostly passive non-violent protestors. It's understandable that police officials, who according to news reports have been coordinating their efforts with conference calls among officials in dozens of cities as well as in federal agencies, blame anarchists, often alleged to be "out of towners". More concerning is that some protestors have done the same, dismissing anarchists - or anyone with a bandana, anarchist or not -- as interlopers, rather than acknowledging them as a defining part of the movement from the very beginning. This development was predictable, but must be overcome if the movement is to persist and strengthen, attracting new participants looking for ways to demand more change than our system is capable of delivering - indeed, more than it is designed to deliver.

Occupying parks has been a useful tactic to direct attention to crucial issues, energize activists through shared excitement and struggle, and create experimental models of self-managed community based on collaborative decision making, mutual aid, and direct action. But there are other ways to focus attention on systemic inequality of resources and power and challenge the myth of the American Dream and the legitimacy of our political-economic system. Occupy has already shown the ability to think and act creatively and flexibly. Maintaining that stance in the face of internal tensions and external repression while resisting pressure to lower our sights is necessary if we are to move from occupying parks toward our real goal: taking back our communities and our lives. 
Contact information/Correspondence:

Dennis Fox

PO Box 35384

Brighton, MA 02135

Email: df@dennisfox.net

Dennis Fox is emeritus associate professor of legal studies and psychology at the University of Illinois at Springfield. He is co-founder of the Radical Psychology Network (http://radpsynet.org) and co-editor of Critical Psychology: An Introduction (Sage, 1997, 2009). His work at the intersection of critical psychology, anarchist theory and practice, and the distinction between law and justice, is available on his website: http://www.dennisfox.net.

\section{References}

Epstein, B. (1993). Political Protest and Cultural Revolution: Nonviolent Direct Action in the 1970s and 1980s. Berkeley, CA: University of California Press.

Fox, D. R. (1985). Psychology, ideology, utopia, and the commons. American Psychologist, 40, 48-58.

Fox, D. (2011). Psychology and anarchism. Theory in Action, 4, 31-48. doi:10.3798/tia.19370237.11029 